\title{
Do We Need to Learn About Human Rights Values?: Jurisprudential Inquiry Model of Teaching in Senior High School
}

\author{
Muhammad Japar, Dini Nur Fadhillah \\ Universitas Negeri Jakarta \\ Jakarta, Indonesia \\ mjapar@unj.ac.id
}

\begin{abstract}
This study aimed to collect the data of human rights values through Jurisprudential Inquiry model of Teaching. This model increases the split society, so we need to appreciate the difference values as an effort to have a sense of unity. Education is the beginning of citizen character building through Civic Education. The process of learning and assessment in Civic Education now emphasizes on the instructional effects limited to content mastery and emphasizes only on the cognitive dimensions and thus a Jurisprudential Inquiry model is required. This qualitative research used the descriptive method of analysis. The results of this study indicated that the Jurisprudential Inquiry model of teaching as an alternative learning of human rights values of students such as religion, tolerance, peace of love, care of social, and responsibility in civic education.
\end{abstract} Inquiry

Keywords-Human Rights, Learning Model, Jurisprudential

\section{INTRODUCTION}

In almost all the world, human rights issues raised as the most important hall in a democratic country or a country that wants to achieve democracy. Teacher's pedagogical perspectives and teaching practices on human rights have important implications for human rights teaching. Teachers' knowledge of subject matter is generally found to greatly influence the effectiveness of their pedagogical practices. Nevertheless, the teacher needs to have learning strategies to develop pedagogy and well explain the material to the students. Hamzah B. Uno [1] argued that the social competence of teachers has become the human nature as social and ethical beings. Teachers should be able to treat learners fairly and aim to achieve the optimization of potential in each learner. They must understand and apply the principles of humanistic learning which assume that the success of learning is determined by the the students' abilities. Instructors only serve them according to their individual needs. The social competence of a teacher is related to the ability to communicate with learners and their environment (such as parents, neighbors, and friends).

In the law constitutions, [2] on Teachers and Lecturers, it is expressed that pedagogic competence is the ability to manage learners. The teacher has to have a good communication to make the student understands and focuses Education in human values should be included as an important element in all subjects and not to be taught as a separate compulsory or optional subject in the school curriculum by a separate specialized teacher. We have to know, education is a process to develop the personality and inherent capabilities of a child. Implementing the learning process is the stage of implementation programs that have been prepared. In this activity, the teacher is demanded to have the ability of being active and creative to improve the student in accordance with the plan that has been prepared. When students have not been able to achieve learning objectives, teachers must be able to make decisions on the basis of appropriate assessments, whether learning activities are adequate, whether the method is changed, and whether past activities need to be repeated. At this stage, in addition to knowledge of learning theories, knowledge of students, skills, and learning techniques are needed, such as teaching principles, teaching aids, teaching methods, and students' learning achievement skills. Effective teachers are teachers who can successfully bring their students to achieve teaching objectives.

Teaching in front of the class is a manifestation of interaction in the communication process. The humanistic paradigm is based on the idea that learners are human beings who have the potential and characteristics of multicultural. In view of this paradigm, learners, both men and women are placed equally. Based on the two paradigms of education, the learning process of Civic Education is directed to the application of humanistic paradigm. By this paradigm a meaningful and functional learning experience can be realized. Knowledge obtained by students can be stored in memory and can lead students to implement learning. From the results of research carried out by [3], Jurisprudential Inquiry is an innovative approach to basic science teaching and an alternative to teaching methods for lecturers. The jurisprudential method is very effective in providing an enjoyable learning experience for students. According to [4], we know morality and humanity are the basis of our existence. Human rights are about bringing morality into human relationships. The UDHR and later international conventions try to regulate these relationships between 
people(s) and states. The notion of the universality of the values and principles of human rights has been much discussed [5]. Most of the criticisms directed at the UHDR come from conservative groups, for example, in Russia and elsewhere in the world [6]. The UDHR (1948) gives freedom to all and to be 'the International Magna Charta of all men everywhere' [7], completing the historical movement from freedom for the few to freedom for all. The role of education in the theory and practice of human rights after five decades of the Universal Declaration of Human Rights. Human rights education is now regarded as indispensable in promoting human rights. As people are educated about their rights and the rights of the others, they are empowered to protect and promote those rights. Human rights values in civic education need to revitalize such as religion, tolerance, peace love, social care, and responsibility.

The learning model according to Joyce [8] is a model that allows learners to respond to social policy. This model is based on a concept of a society that has different views and priorities [9]. The learning model pioneered by Donal Oliver and James P Shaver is based on the understanding of society that everyone is different from each other's views and priorities, and their social values confront each other [1]. Complex and controversial problem-solving within the context of productive social rules requires citizens who can talk to each other and negotiate about the differences. Therefore, education must be able to produce individual prospective citizens who can overcome the conflict of difference in various respects. As student's nature, the study of social science at the community, state, national, and international levels can be made available to them [9]. The jurisprudential model is designed for this purpose. It is created especially for secondary students in the social studies, the model brings the case-study method, reminiscent of legal education, to the process of schooling. Students study the cases of social problems in which public policy needs to be made such as on issues of justice and equality, poverty and power. They are led to identify the public policy issues as well as options for dealing with them and the values underlying those options. Although the social studies develop, this model can be used in any area having public policy issues and most curriculum areas around them. This learning model helps students to learn to think systematically about contemporary issues happening in society. By giving those ways of analyzing and discussing social issues, this learning model assists students to participate in redefining social values. Teaching jurisprudential is designed primarily to teach the jurisprudential framework as a way of thinking and solving social issues [10].

In general, the key to the success of this model is through the Socratic dialogue method (confrontational debate). The steps to be taken include, in the first stage, teachers introduce students to the case materials by reading stories, watching movies, depicting value conflicts, or discussing trending events in the surrounding life, school life or community. The second step that belongs to the orientation stage is to review the facts by describing the events in the case, analyzing the who, what, and why. In the second phase, students synthesize facts, relate them to common issues and identify the values involved in the case (for example, the issue concerning freedom of expression, regional autonomy, equality of rights, etc.). In this stage, one and two of these students have not been asked to express their opinions or attitudes towards the case. In the third stage, students are asked to take a position (attitude/opinion) on the issue and express their attitude. For example, in the case of school fees, students state their attitude that the government should not determine the number of school fees that must be applied to each school because it violates the autonomy of the school. In the fourth stage, students' position (position/opinion) is dug deeper. Master now plays a Socratic role.

Arguing the students' opinions with confrontational opinions. In this case, the students are tested for consistency in maintaining the attitude/and opinion that has been taken. Here, the students are required to propose a logical and rational argument that can support the statement (position) they have made. The fifth stage is re-determination of the position (attitude) that students have taken. In this stage, the attitude (position) the student has taken may be consistent (persistent) or change (inconsistent) depending on the outcome or argument that occurs in the fourth stage. If student has strong arguments, he/she may be consistent. If not, perhaps the student change his/her attitude. In the sixth stage, it is the factual assumption that underlies the students' attitude. In this stage, the teacher discusses whether the arguments used to support the attitude statement are relevant and valid. Thus, it can be said that this model emphasizes on the student's individual ability in behaving towards an issue or problem based on beliefs and learning resources mastered. In addition, this model is more structured in the learning process, meaning students can follow the scenario that has been made by the teacher. In relation to the role of teachers, the teachers appear to be still dominant in teacher-centered tendencies, especially in the fifth stage when the teachers explore students' attitudes in Socratic discussions.

In Japan, Citizenship education can be expected to become wider and richer as it is associated with new curricula which are concerned with the concept of citizenship. Human rights education which has been developed mainly by the education for Buraku (a minority group in Japan) Liberation involves civil, political and social rights. Multicultural education was begun with ethnic education for Korean-Japanese children in 1970s and is now moving to the children from the other Asian countries and Japanese-Brazilian children. This education is concerned with civic identity and human rights of minority people. Environmental education provides ecological perspectives which are more and more essential in the 21 st century. Peace education in Japan had focused for a long time on the study of war history [11]. However, in Thailand, the trend towards globalization together with the era of the development of an information-based society has significant effects on Thai society with both desirable and undesirable impacts. The quality of life of Thai people is thus the key factor to enable the society to develop in the right direction. For this reason, civics education is recognized as a principal goal of schooling. 
Civics education in Thailand is based on Buddhism, the Thai culture, the institution of the monarchy, family values and the Thai way of life. Civic education in Indonesia has the curricular subjects of civic education which are mandated to provide human rights learning; it can be seen from law constitution [12] and basic competence where the concept of human rights can be seen at the senior high school level in class XI Basic Competence 3.1 on Analyzing human rights violations in the perspective of Pancasila in the life of nation and state, then Basic Commencement 4.1 on Abilities Presenting results of analysis of human rights violations in the perspective of Pancasila in the life of nation and state. Nevertheless, as a civic education teacher, of course, he/she has more moral responsibility than the other teachers in the effort to teach the values of human rights, it is related to the conception of human rights in civic education learning. So, on this occasion, I will try to elaborate how to teach human rights values on civic education learning in school.

Indonesian ideology is Pancasila, as a practical formula in an effort to cultivate the values of human rights. We believe this case because Pancasila has a strong philosophical value that can be described to the values of praxis in real life. The Discussion of Pancasila is philosophically held to the essence of the deepest (to the point the deepest). Hence, this notion of knowledge of the deepest knowledge is also the deepest knowledge which is the essence of essence, abstract and universal essence of Pancasila that is fixed and unchanged [13].

\section{METHOD}

The case portrayed in this article stems from a larger multi-cases study. I used qualitative methods to collect observational case studies in this research [14]. Jurisprudential inquiry learning in teaching human rights material in Senior High School. A qualitative approach is warranted when the nature of research questions requires exploration [15]. This study was conducted in three phases. The first observation to class interviews teacher and students and analyze documents. The qualitative data in the first phase of the study were collected from the classroom observations in the one participating school.

\section{A. Natural Knowledge Science Class}

The observations in this class were conducted while the researcher administered the questionnaire. The class has 40 students. Student activity is orderly. From the 40 students, nearly 30 students were asked about the material that had been submitted by the teacher with the questions of the analysis phase. The teacher opened the lesson by inviting the students to sit by their own group and inviting each group of pros and cons to show their yells first. The teachers first redoubt the basic competencies so that the students understood what they should get after the lesson ended. After that, the teacher directly explained the notion of Human Rights, Human Rights Substance and provided one of the topics of the Case of Human Rights and they were given the opportunity to choose the pros or cons in the case. Therefore, the student were given the freedom to express their opinions on the reasons for choosing the pros and cons.

\section{B. Social Science Class}

This class had the same situation as the previous class. From 37 students, only 1-2 students who have not had the motivation to participate in the discussion. The data were collected at SMA Negeri 1 Cibungbulan Bogor. However, to orient the case and identify the issue, it was the time for the student to choose a position on the case already provided. The pro group was the group that agreed, while the counter group was the less-favored group. After identifying the issue, the teacher gave the student the opportunity to choose the position of the case described. So, the discussion did not go out of the flow and the students remain excited about giving the reasons of why they chose a different position. Civics education learning becomes more interesting by using Jurisprudential Inquiry.

From the observation, the teacher gave the material according to the existing curriculum. The students could follow the learning process well so that the application of Jurisprudential Inquiry model learning provided new innovation to the students.

\section{RESULT AND DISCUSSION}

The study found that there were five aspects that were developed when using jurisprudential inquiry model in Human Rights material in civic education which were religion, tolerance, peace of love, care of social, and responsibility in civic education. The implementation of human rights in school, through the philosophical system above, can be described in detail as follows.

\section{A. Religion}

First aspect is providing space and time for each student to be able to run the worship according to their religion and belief. Adequate religious facilities include religious teachers in it as a human rights is the manifestation of God Almighty, the most basic human rights. The competence leads students to live and practice the religious teachings that they embraces.

The first thing Teacher did when opening lessons was praying. Then, we were invited to be grateful to the Heroes of Independence because we got the opportunity to learn without fear of the invaders.

Praying is one of the activities we do before the learning process. It is because by praying we hope that the knowledge given by the teacher can be well understood.

In every learning process, we are invited to pray and it becomes a habit before starting lessons or tests.

From the interview talking that education in Indonesia, especially civic education, develops a religious attitude that students are expected to live and practice the teachings of a religion they embrace. Praying is a manifestation of the core competencies that exist within the curriculum to enhance students' gratefulness toward God Almighty. 


\section{B. Tolerance}

Human rights lead to human high values that are universal, so that humanity in Indonesia is a universal humanity. It is significant to teach universal values such as honesty, fairness, responsibility, respect, tolerance, empathy, discipline, hard work, loving each other, caring, etc. where all human groups including religion teach the same thing. In Human Rights materials, teachers provide lessons on Human Rights and Obligations in the Basic Values of Pancasila or Five Values. Then, students gain knowledge of Human Rights and Obligations in the Value of Pancasila Practice.

Learning to analyze the Human Rights makes me understand that every human being has the freedom to move, express opinions, choose, embrace and practice each religion according to their belief. However, we were also given the opportunity to understand our obligation to respect the rights of the others.

The Jurisprudential Inquiry learning model enabled students to respect the rights of their peers and grow tolerance especially on the understanding of human rights materials. They not only understood the theory but also could practice in everyday life.

Teachers provided movie/ or video shown from various sources. Then, we were given the opportunity to observe and analyze. I feel grateful that these violations did not happen to me. However, by looking at these impressions, I, as a youth should be able to appreciate the differences especially have an attitude of tolerance.

The tolerance illustrated by the students from the interview shows that Jurisprudential Inquiry is a learning model that is compatible with human rights materials to develop the character of tolerance to the students. It means recognizing equality, equality of rights and basic human obligations without distinction of race, heredity, religion, belief, gender, social standing, and skin color and so on. This case shows that the key to the birth of a wisdom is to be wise from wise men so that their words and behavior are full of wisdom (benefits); this case is certainly based on an understanding of the strong distinction, giving rise to the concept of "tolerance" in the difference. That concept will become a strong bond of mutual agreement to be built. Although to build tolerance is certainly not easy, the learning needs that should be done are understanding who he is, understanding the other people and the environment, being able to communicate the differences, giving the understanding of difference as long as not disturbing our human rights, if disturbing we have to discuss well, logically and rationally, not only focusing on differences, but the equations should be awakened, hearing to the others so as to increase our understanding of the others to build tolerance and synergy, not in words but deeds and continuing to do that.

\section{Peace of Love}

Human Rights materials provide students with an understanding to develop a peaceful, tolerant and nonarbitrary attitude towards the others such as developing a respectful attitude among students. Human rights can only be restricted by the other human rights, implemented in state legislation so that subsequent forest planting is to invite all citizens to comply with the rule of law applied as the manipulation of the exercise of the Human rights that are high on Indonesian unity. So, even though the humanity of the Indonesian nation has a universal value but it still appreciate the values of national life as a nation of Indonesia.

Because of the implementation of Jurisprudential Inquiry on civic education lessons with human rights materials, the students became easier to understand the importance of peace love. The students were expected to respect and protect human rights as a form of the value of Pancasila (five values) so as to create harmony and unity. The students demonstrated this thing by respecting the opinions of their friends and starting to solve the problem with a nonemotional attitude.

\section{(Teacher Interview, 2017)}

A very significant difference was found since using the Jurisprudential Inquiry model of learning. Usually, students only understand in theory, but with this learning model students are invited to develop a sense of love towards the homeland and other communities. Maintaining the order is by not interrupting the learning process, then, not interfered with the rights of the other students and promoting the association with no discrimination.

\section{(Teacher Interview, 2017)}

As a high school, senior students and our citizens are happy if the surrounding environment is peaceful. Given the task of collecting data from various sources including print and electronic media on cases of human rights violations, we were then given the opportunity to analyze. By this kind of learning we understand to create peace love, it is necessary to keep each other's human rights mutually. Peace is manifested from mutual respect. I really enjoy learning human rights. Civic education makes me want to continue to learn and understand the social environment.

Human rights are based on the awareness of differences, so that it must be built to differentiate and even empower the difference by building a synergy. So, the difference is not a threat to a wealth and power. This is a manifestation of the implementation of human rights based on democracy, led by the wisdom policy in deliberations. The results of the above interviews proved that to create peace is started from the smallest thing. One of them is by instilling a peaceful love attitude in the classroom and in the learning process. The existence of connectivity between teachers and students form the character development through civic education materialized.

\section{Care of Social}

Human rights must build social justices So that human rights learning should be able to touch the sense of social justice for all students. Students are invited to understand the surroundings, and build a sense of empathy and solidarity among people (social responsibility), so that the learning of human rights can be done by way of learning to give knowledge of attitude, providing a broad insight into the life 
of the surrounding environment, its advantages and disadvantages, analyzing the problem, making a problemsolving study, learning to create a joint policy to create a solution.

Human Rights material was very interesting to learn because it increased my sense of concern for the rights of the others. As a student, I feel that we should have an obligation to protect human rights such as not denouncing friends who have shortcomings or differences, and when you see a friend who is bullied, we must care to help him.

The teacher made us understand the case given. Teachers also did not blame when we chose the pros as well as the cons with the case. However, we were given the opportunity to give a reason for the case. From that case, we were taught to care for social life.

The results of the above interviews provided a picture that civic education through human rights materials using jurisprudential inquiry model can increase social awareness in students. Thus, students are expected to be more sensitive to various actions that threaten the human rights of the others, both in the school environment, residence and the wider community. Hence, precautions can be taken as quickly as possible.

\section{E. Responsibility}

Human rights are not merely material to be learned. Through the concept of human rights, there are some efforts to uphold human rights.

As an Indonesian nation, our responsibility for human rights is to safeguard the rights and perform obligations as a good citizen. As a students, we should not hurt friends and keep the friends' feelings and teachers' alike.

The process of learning in the classroom made us responsible for conducting discussions well. In theory, we were given by teachers an understanding of our responsibilities as a good citizen. Nevertheless, in practice, the teacher gave an example to be responsible in the learning process, not interfered with the learning process, following the school rules, listening to the orders of both parents and study earnestly.

This learning was interesting because it was not just the theory but the students were invited to participate in practicing every character value that want to be developed in human rights material. One of them is responsibility. The teacher provided a tangible example that the teacher was responsible for teaching well and on time. So, the students had the responsibility to enter the class on time.

Basically, every human has a responsibility. From the interview results, the students increased their responsibility in the class. They felt interesting to participate in learning process. In the book, the role of the state is needed for the protection, promotion, and fulfillment of human rights. As well as us as students who are also the part of the Indonesian citizens. The students were not only given knowledge of rights and obligations. However, through the jurisprudential inquiry model, the students were invited to give examples such as the obligation to respect human rights without offending race, and religion, not bullying and upholding common interests and respecting the others' opinions. However, these responsibilities have differences in behavior when at home, at school, and in the social environment.

From the findings, the students and teachers had good connections and cooperation in the learning process. From previous research, jurisprudential inquiry gave positive results. It is also seen that the Jurisprudential Inquiry learning model is very much in line with the human rights materials that exist in civic education in Senior High School. Therefore, the Jurisprudential Inquiry model of teaching as an alternative learning can revitalize the human rights values such as religion, tolerance, peace of love, care of social, and responsibility in civic education.

\section{CONCLUSION}

In senior high school, to implement human rights values in civic education, Jurisprudential Inquiry builds students' motivation to develop the character and values that exist in human rights materials. Students not only learn to listen to but also able to analyze and give opinions. Teachers as leaders in the class are not just giving lectures but also providing opportunities for students to develop their knowledge by analyzing each given case. In addition, the cooperation between teachers and students can be seen from the active classes and the teacher who can give an example to the students in real accordance with the given material. Fostering mutual caring and caring are the values that exist in civic education. This study also showed that jurisprudential inquiry can be used as an alternative model of civic education. Moreover, the results of interviews can be used as a reference to make students feel comfortable in learning civic education.

\section{REFERENCES}

[1] B. Uno and H. Hamzah, Model Pembelajaran Menciptakan Proses Belajar Mengajar yang Kreatif. Jakarta: Bumi Aksara, 2007.

[2] Act of The Republic of Indonesia No. 14, Teachers and Lecturers. Republic of Indonesia, 2005.

[3] C. E. Nwafor, "Use Of Jurisprudential Innovative Approach in Teaching Basic Science: An Alternative to Lecture Method," Int. Res., vol. 3, no. 1, pp. 63-67, 2014.

[4] D. Grossman, Admen met beide longen (Breathe with both lungs). Amsterdam: Stichting Collectieve Propaganda van het Nederlandse Boek, 2015.

[5] A. Allan, "Are human rights redundant in the ethical codes of psychologists?," Ethics Behav., vol. 23, no. 4, pp. 251-265, 2013.

[6] R. Coalson, "Russian conservatives challenge notion of 'universal' values,"www.rferl.org, 2008.

[7] R. Eleanor, "The struggle for human rights," www.geocities.com, 1948. .

[8] B. Joyce and W. Marsha, Models of Teaching, Third Edit. New Jersey: Prentice Hall, 1980.

[9] B. Joyce, W. Marsha, and C. Emily, 8th edition Model of Teaching. Pearson Education, Inc, 2009.

[10] R. Rusman, Model-Model Pembelajaran Mengembangkan Profesionalisme Guru. Jakarta: PT. Raja Grafindo Persada., 2010.

[11] J. J. . Cogan and D. Ray, Citizenship for the 21st Century an International Perspective on Education. London: Kogan Page Limited, 1998. 
[12] Act of The Republic of Indonesia No. 24, Core Competence. 2016.

[13] K. Kaelan, Pendidikan Pancasila Pendidikan untuk Mewujudkan Nilai-nilai Pancasila, Rasa Kebangsaan dan Cinta tanah Air Sesuai dengan SK. Dirjen Dikti No. 43/Dikti/Kep/2006. Yogyakarta: Paradigma, 2014.

[14] R. Bogdan and S. Biklen, Qualitative Research for Education. An Introduction to Theories and Methods. London: Pearson, 2003.

[15] R. Stake, The art of case study research. Thousand Oaks, CA: SAGE publications Inc, 1995. 